\title{
ANALISIS PORTOFOLIO OPTIMAL DENGAN MENGGUNAKAN MODEL INDEKS TUNGGAL
}

\author{
Maria Yosefa T. Kein ${ }^{1}$, Wehelmina M. Ndoen ${ }^{2}$, Paulina Y. Amtiran ${ }^{3}$ \\ 1,2,3 Universitas Nusa Cendana, keinyosefa@ gmail.com; wehelmina.ndoen@staf.undana.ac.id; \\ paulinaamtiran@staf.undana.ac.id
}

\begin{abstract}
ABSTRAK
Penelitian ini bertujuan untuk menentukan portofolio saham optimal sebagai dasar penetapan investasi pada saham perusahaan yang berada dalam perusahaan makanan dan minuman yang terdaftar di Bursa Efek Indonesia. Periode penelitian yang digunakan adalah periode 2015-2019. Penelitian ini merupakan penelitian kuantitatif deskriptif. Populasi penelitian adalah 20 perusahaan yang berada dalam perusahaan makanan dan minuman yang terdaftar di Bursa Efek Indonesia periode 2015-2019. Pemilihan sampel ditentukan dengan teknik purposive sampling dengan kriteria adalah 1). Perusahaan makanan dan minuman yang terdaftar di Bursa Efek Indonesia dari tahun 2015-2019, 2). Perusahaan yang menerbitkan laporan keuangan tahunan di Bursa Efek Indonesia secara berturut-turut selama tahun pengamatan dari tahun 2015-2019, 3). Perusahaan makanan dan minuman tidak memiliki krisis keuangan selama periode 2015-2019, sehingga diperoleh sampel sebanyak 8 saham. Metode yang digunakan dalam penelitian ini adalah model indeks tunggal. Hasil penelitian ini menunjukkan bahwa dari 8 saham yang dijadikan sampel, terdapat 2 saham yang masuk kedalam kandidat portofolio optimal. Kedua saham tersebut adalah perusahaan Parasida Aneka Niaga (PSDN) dan perusahaan Wilmar Cahaya Indonesia (CEKA) dengan proporsi dana masing-masing sebesar 0,9470\% dan 0,0530 Kedua saham tersebut mempunyai nilai expected return yang akan diperoleh investor sebesar 0,0113 $(1,13 \%)$ dengan risiko yang akan ditanggung oleh investor atas investasi yang dilakukan yaitu sebesar $0,1092(10,92 \%)$.
\end{abstract}

Kata Kunci : Analisis, Expected Return, Portofolio Optimal, Return, Risiko

\begin{abstract}
This study aims to determine the optimal stock portfolio as a basis for determining investments in company shares in food and beverage companies listed on the Indonesia Stock Exchange. The research period used is the period 2015-2019. This research is a descriptive quantitative research. The study population was 20 food and beverages listed on the Indonesia Stock Exchange in the 2015-2019 period. The sample selection is determined by purposive sampling technique with the criteria are 1). Food and beverage companies listed on the Indonesia Stock Exchange from 2015-2019, 2). Companies that publish annual financial reports on the Indonesia Stock Exchange in a row during the observation year from 2015 -2019, 3). Food and beverage companies did not have a financial crisis during the 20152019 period, so a sample of 8 shares was obtained. The method used in this study is a single index model.The results of this study show that of the 8 stocks that were sampled, there were 2 stocks that entered into the optimal portfolio candidates. The two shares are Parasida Aneka Niaga (PSDN) and Wilmar Cahaya Indonesia (CEKA), with a proportion of funds of 0,9470 and 0, 0530 Both of these shares have an expected return value that will be obtained by investors amounting to 0.0113 (1.13\%) with the risk to be borne by investors for investments made in the amount of 0.1092 (10.92\%).
\end{abstract}

Keywords: Analysis, Expected Return, Optimal Portfolio, Return, Risk

Naskah diterima : 08-02-2021, Naskah dipublikasikan : 30-04-2021 


\section{PENDAHULUAN}

Pada era modern investasi dalam bentuk kepemilikan aset finansial lebih menjanjikan, sehingga masyarakat di Indonesia lebih memilih aset finansial dari pada aset riil. Tempat ataupun kegiatan yang menjadi pemasaran aset finansial adalah pasar modal. Pasar modal adalah kegiatan yang berkaitan dengan penawaran umum dan perdagangan efek perusahaan publik yang diterbitkan serta lembaga dan profesi yang berkaitan dengan efek (Qudsi, 2009).

Salah satu teknik analisis portofolio optimal yang dilakukan oleh Elton dan Gruber (1995), adalah menggunakan indeks tunggal. Analisis atas sekuritas dilakukan dengan membandingkan excess return to beta dengan Cut-off rate-nya dari masing-masing saham. Saham yang memiliki excess return to beta lebih besar dari Cut off rate dijadikan kandidat portofolio, sedang sebaliknya yaitu Cut off rate lebih besar dari excess return to beta tidak diikutkan dalam portofolio. Excess return to beta merupakan kelebihan return saham atas return aset bebas risiko (risk free rate) yang disebut dengan return premium per unit risiko yang diukur dengan beta. Excess return to beta digunakan untuk mengukur return premium saham relatif terhadap satu unit risiko yang tidak dapat diversifikasikan yang diukur dengan Beta. Excess return to beta menunjukkan hubungan antara return dan resiko yang merupakan faktor penentu investasi. Sedangkan Cut-off-rate merupakan hasil bagi varian pasar dan return premium terhadap variance error saham dengan varian pasar pada sensitivitas saham individual terhadap variance error saham.

Metode indeks tunggal merupakan metode yang relatif sederhana dan mengurangi variabel yang dihitung, dengan periode yang lebih lama dan sampel yang lebih banyak, maka akan diperoleh hasil yang lebih akurat dan dapat menjawab masalah atas ketidakpastian investasi saham. Model indeks tunggal dipilih karena lebih sederhana untuk diterapkan, yaitu dengan menyederhanakan perhitungan model Markowiz dengan menyediakan parameter-parameter input yang dibutuhkan dalam perhitungan model Markowiz (Jogiyanto,2014). Disamping itu model indeks tunggal dapat digunakan untuk menghitung return dari risiko sebuah saham atau portofolio (Zubir,2011). Model tersebut mengasumsikan bahwa pergerakan return saham hanya berhubungan dengan pergerakan pasar. Jika pasar bergerak naik, dalam artian pergerakan dalam saham sangat meningkat, maka harga saham di pasar akan naik juga. Sebaliknya, jika pasar bergerak turun, maka harga saham akan turun juga.

Beberapa penelitian yang mengkaji tentang pemilihan saham dan portofolio optimal antaranya Yuniarti (2010), Suryani (2015), Oktaviani \& Wijayanyo (2016), Soebrati \& Astawinetu (2017) pembentukan portofolio optimal dengan menggunakan model indeks tunggal ada beberapa tahap yang harus dilakukan. Selain itu peran Beta sebagai indikator terhadap volatilitas return dapat mempengaruhi tingkat pengembalian dari suatu saham.

Mulyati dan Murni (2018) menyatakan bahwa nalisis investasi portofolio optimal dengan model indeks tunggal pada kelompok saham IDX 30 berdasarkan penelitian yang dilakukan oleh peneliti maka terdapat tujuh perusahan yang masuk kedalam portofolio optimal dan perusahaan tersebut adalah LPKR, PGAS, PTPP,SMGR, SRIL,UNTR, dan UNVR.

Perusahaan sektor makanan dan minuman Indonesia dikenal tahan krisis. Sektor industri ini mempunyai peluang untuk tumbuh dan berkembang meskipun kondisi ekonomi saat ini tidak begitu baik. Berkembang pesatnya industri makanan dan minuman ini sangat ditunjang populasi penduduk Indonesia yang besar, walaupun terjadi krisis ekonomi, kelancaran produk industri makanan dan minuman akan tetap terjamin, karena industri bergerak pada bidang pokok manusia. Berikut perkembangan harga saham pada perusahaan makanan dan minuman pada tahun 2015-2019 yang ditunjukkan tabel 1 : 
Tabel 1. Perkembangan Harga Saham Pada Perusahan Makanan dan Minuman di Bursa Efek Indonesia

\begin{tabular}{lrrrrr}
\hline Emiten & \multicolumn{1}{c}{2015} & \multicolumn{1}{c}{2016} & \multicolumn{1}{c}{2017} & \multicolumn{1}{c}{2018} & \multicolumn{1}{c}{2019} \\
\hline CEKA & 755,00 & 675,00 & $1.350,00$ & $1.290,00$ & $1.375,00$ \\
DLTA & $7.800,00$ & $5.175,00$ & $5.000,00$ & $4.590,00$ & $5.500,00$ \\
ICBP & $6.550,00$ & $6.575,00$ & $8.575,00$ & $8.900,00$ & $10.450,00$ \\
INDF & $6.850,00$ & $5.175,00$ & $7.925,00$ & $7.625,00$ & $7.450,00$ \\
MLBI & 12.000 .00 & $8.025,00$ & $11.750,00$ & $13.675,00$ & $16.000,00$ \\
PSDN & 143,00 & 122,00 & 134,00 & 256,00 & 192,00 \\
ROTI & $1.385,00$ & $1.265,00$ & $1.600,00$ & $1.275,00$ & $1.200,00$ \\
SKBM & 970,00 & 945,00 & 640,00 & 715,00 & 695,00 \\
Jumlah & $36.450,00$ & $27.957,00$ & $36.979,00$ & $38.326,00$ & $42.862,00$ \\
Rata-rata & $4.556,25$ & $3.494,625$ & $4.622,375$ & $4.790,750$ & $5.357,750$ \\
\hline
\end{tabular}

Sumber : yahoo finance, 2019

Tabel 1 menunjukkan bahwa terjadi fluktuasi harga saham pada perusahaan makanan dan minuman. Hal ini mengindikasikan adanya unsur risiko, dimana salah satu risiko yang dapat terjadi adalah pelemahan nilai tukar rupiah terhadap dollar amerika. Hal ini tentunya memberikan dampak positif dan negatif bagi harga saham perusahaan. Meskipun saham-saham pada perusahaan makanan dan minuman memiliki likuiditas dan frekuensi perdagangan yang stabil namun tidak lepas dari ketidakpastian akan tingkat pengembalian yang akan diterima investor. Oleh karena itu investor harus mempertimbangkan berbagai risiko yang dapat terjadi sehingga mampu mengantisipasi untuk mencapai keuntungan yang optimal dari setiap investasi yang dilakukan.

Berdasarkan kondisi tersebut maka perlu dilakukan kajian lebih lanjut untuk menilai portofolio saham yang optimal dengan menggunakan model indeks tunggal pada perusahaan makanan dan minuman yang terdaftar di Bursa Efek Indonesia.

\section{KAJIAN LITERATUR \\ Teori Investasi}

Menurut Tandelilin (2017) investasi adalah komitmen atas sejumlah dana atau sumber daya lainnya yang dilakukan pada saat ini, dengan tujuan memperoleh keuntungan di masa yang akan datang. Sedangkan investor membeli sejumlah saham saat ini dengan harapan memperoleh keuntungan dari kenaikan harga saham atau sejumlah deviden dimasa mendatang. Sebagai imbalan atas waktu dan risiko yang terkait dengan investasi tersebut. Proses keputusan investasi terdiri dari 5 (lima) tahap keputusan berjalan terus-menerus sampai keputusan investasi yang berbaik. Menurut Tandelilin (2017) Tahaptahap keputusan investasi tersebut adalah sebagai berikut: a) Penentuan tujuan investasi ; b) Penentuan kebijakan investasi ; c) Pemilihan strategi portofolio ; d) Pemilihan aset ; e) Pengukuran dan evaluasi kinerja portofolio.

\section{Teori Portofolio}

Teori portofolio pertama kali dicetuskan oleh Harry M. Markowitz pada tahun 1952 yaitu menyatakan bahwa risiko pengembalian keduanya harus dipertimbangkan dengan asumsi tersedia kerangka formal untuk mengukur keduanya dalam pembentukan portofolio. Dalam bentuk dasarnya dimulai dengan asumsi bahwa tingkat pengembalian atas efek dimasa depan diestimasi dan kemudian menentukan risiko dengan variasi distribusi pengembalian. Dengan asumsi tertentu teori portofolio menghasilkan hubungan linear antara risiko dan pengembalian.

Markowitz menjabarkan cara mengkombinasikan aset ke dalam diversifikasi portofolio efisien. Dalam portofolio ini dapat dikurangi dengan menambah jumlah jenis aset kedalam portofolio dan tingkat expected return dapat naik jika investasinya terdapat perbedaan pergerakan harga aset-aset yang dikombinasikan tersebut. Portofolio adalah gabungan dari berbagai instrumen investasi baik yang 
terbentuk tanpa sengaja atau memang diputuskan melalui perancangan yang didukung dengan perhitungan dan pertimbangan rasional untuk memaksimumkan risiko investasi (Sulistiyowati, 2017).

\section{Return}

Menurut Firdaus (2015) return merupakan tujuan para investor dalam berinvetasi untuk memaksimalkan return yang diharapkan, biasanya para invesor menyiasatkan dengan portofolio saham dan salah satu cara untuk mengurangi risiko investasi saham bisa dilakukan dengan melakukan diversifikasi kepemilikan saham yaitu dengan mengkombinasikan berbagai saham dalam invetasinya atau dengan membentuk portofolio. Return saham adalah tingkat pengembalian yang didapat melalui sejumlah investasi pada saham, return saham dihitung dengan rumus (Jogiyanto, 2014) :

\section{Risiko}

$$
R_{i}=\frac{P_{t}-P_{t-1}+D_{t}}{P_{t-1}}
$$

Risiko adalah kemungkinan terjadinya kerugian atau return negatif dari suatu investasi (Syahyunan, 2015). Risiko investasi di pasar modal pada dasarnya terdiri atas risiko sistematis dan risiko tidak sistematis. Risiko sistematis merupakan risiko yang tidak dapat dihilangkan karena risiko yang terjadi disebabkan oleh faktor-faktor makro yang mempengaruhi pasar secara keseluruhan, sementara risiko tidak sistematis merupakan risiko yang dapat diminimalisir tingkat risikonya.

Jogiyanto (2014) menunjukkan bahwa secara umum risiko mungkin dapat dikurangi dengan menggabungkan beberapa sekuritas tunggal ke dalam bentuk portofolio. Persyaratan utama untuk dapat mengurangi risiko didalam portofolio ialah return untuk masing-masing sekuritas tidak berkorelasi secara positif dan sempurna.

\section{Model Indeks Tunggal}

Jogiyanto (2014) mengatakan model indeks tunggal adalah merupakan metode pengukuran risiko sistematis (beta) dimana faktor berpengaruh pada harga saham diwakili oleh sebuah variabel, yaitu variabel return pasar. Model ini secara khusus dikembangkan guna menyederhanakan perhitungan dari variabel-variabel yang dibutuhkan dalam perhitungan simpangan rata-rata Return pasar. Model penyederhanaan ini dikembangkan Markowitz. Sharpe (1963) mengembangkan model pasar yang merupakan bentuk hubungan antara tingkat keuntungan aset individual dengan tingkat keuntungan ratarata pasar (market indeks).

Jogiyanto (2014) mengatakan bahwa model indeks tunggal didasarkan pada pengamatan bahwa harga dari suatu sekuritas berfluktuasi searah dengan indeks harga pasar. Secara khusus dapat diamati bahwa kebanyakan cenderung mengalami kenaikan harga jika indeks harga saham naik. Dengan dasar ini, return dari suatu sekuritas dan return dari indeks pasar yang umum dapat dituliskan:

$$
\mathrm{Ri}=\alpha \mathrm{i}+\beta \mathrm{i} . \mathrm{Rm}
$$

\section{METODE PENELITIAN}

Pendekatan penelitian yang digunakan dalam penelitian ini adalah pendekatan deskriptif kuantitatif. Jenis data yang digunakan dalam penelitian ini adalah data kuantitatif merupakan data berbentuk angka. Data yang dimaksud adalah data harga saham, indeks harga saham gabungan dan suku bunga selama periode penelitian 2015-2019.

Unit analisis penelitian ini adalah perusahaan makanan dan minuman yang terdaftar di Bursa Efek Indonesia periode 2015-2019. Populasi perusahaan makanan dan minuman yang terdaftar di Bursa Efek Indonesia pada saat periode penelitian berjumlah 20 perusahaan, tampak pada tabel 2 berikut 
Tabel 2. Daftar Perusahaan Makanan dan Minuman Yang Terdaftar di BEI

\begin{tabular}{ccc}
\hline No & Kode & Nama Emiten \\
\hline 1 & ADES & Akasha Wira International Tbk \\
2 & AISA & Tiga Pilar Sejahtera Food Tbk \\
3 & ALTO & Tri Banyan Tirta Tbk \\
4 & BTEK & Bumi Teknokultura Unggul Tbk \\
5 & BUDI & Budi Starch \& Sweetener Tbk \\
6 & CEKA & Wilmar Cahaya Indonesia Tbk \\
7 & DLTA & Delta Djakarta Tbk \\
8 & ICBP & Indofood CBP Sukses Makmur Tbk \\
9 & IIKP & Inti Agri Resources Tbk \\
10 & INDF & Indofood Sukses Makmur Tbk \\
11 & MGNA & Magna Investama Mandiri Tbk \\
12 & MLBI & Multi Bintang Indonesia Tbk \\
13 & MYOR & Mayora Indah Tbk \\
14 & PSDN & Prasidha Aneka Niaga Tbk \\
15 & ROTI & Nippon Indosari Corpindo Tbk \\
16 & SKBM & Sekar Bumi Tbk \\
17 & SKLT & Sekar Laut Tbk \\
18 & STTP & Siantar Top Tbk \\
19 & TBLA & Tunas Baru Lampung Tbk \\
20 & ULTJ & Ultra Jaya Milk Industry \& Trading Company \\
& & Tbk
\end{tabular}

Sumber : IDX, 2019

Penentuan sampel pada penelitian ini adalah dengan menggunakan teknik purposive sampling, yaitu metode pemilihan sampel berdasarkan kriteria tertentu sesuai dengan tujuan penelitian, adapun kriteria yang digunakan adalah sebagai berikut : 1) Perusahaan makanan dan minuman yang tedaftar di Bursa Efek Indonesia pada tahun 2015-2019 ; 2) Perusahaan tersebut menerbitkan laporan keuangan tahunan di Bursa Efek Indonesia secara berturut-turut selama tahun pengamatan dari tahun 2015-2019 ;3) Perusahaan makanan dan minuman yang tidak memiliki krisis keuangan selama periode 2015-2019.

Dari kriteria tersebut diperoleh 8 perusahaan makanan dan minuman yang terdaftar di Bursa Efek Indonesia yang dijadikan sampel dalam penelitian ini. Tabel 3 data perusahaan yang dijadikan sampel penelitian sebagai berikut:

Tabel 3. Sampel Perusahaan Makanan dan Minuman Yang Terdaftar di BEI

\begin{tabular}{ccc}
\hline No & Kode & Nama Emiten \\
\hline 1 & CEKA & Wilmar Cahaya Indonesia Tbk \\
2 & DLTA & Delta Djakarta Tbk \\
3 & ICBP & Indofood CBP Sukses Makmur Tbk \\
4 & INDF & Indofood Sukses Makmur Tbk \\
5 & MLBI & Multi Bintang Indonesia Tbk \\
6 & PSDN & Prasidha Aneka Niaga Tbk \\
7 & ROTI & Nippon Indosari Corpindo Tbk \\
8 & SKBM & Sekar Bumi Tbk \\
\hline
\end{tabular}

Sumber : Sampling Data, 2019 
Teknik analisis data yang digunakan dalam penelitian ini mengggunakan model indeks tunggal dengan beberapa tahap estimasi, yaitu : (a) mengestimasi return saham ; (b) menentukan expected return ; (c) menentukan return market; (d) menentukan risk free ; (e) menghitung excess return ; (f) mengestimasi varians Beta, Alpha, excess to beta; $(\mathrm{g})$ menentukan nilai cut off rate $(\mathrm{Ci})$ \& cut off point $\left(\mathrm{C}^{*}\right)$; (h) menentukan portofolio optimal.

\section{HASIL PENELITIAN}

Hasil penelitian dalam proses pembentukan portofolio optimal saham berdasarkan model indeks tunggal adalah sebagai berikut:

\section{Analisis Return Saham (Ri)}

Return saham dihitung dengan mengurangkan harga saham periode saat ini dengan harga saham periode terdahulu dibagi dengan periode terdahulu dimana, harga saham individual ini didasarkan pada perubahan closing price saham perbulannya.

Nilai return tertinggi pada perusahaan CEKA sebesar 0,5175 pada bulan Februari 2016 dan return terendah pada Desember 2019 sebesar -1,0000, return tertinggi pada perusahaan DLTA adalah sebesar 0,1465 pada bulan Februari 2017 sedangkan return terendah pada perusahaan DLTA adalah sebesar -1,0000 pada Desember 2019, return tertinggi pada perusahaan ICBP adalah sebesar 0,1599 pada Desember 2017 dan return terkecil pada perusahaan ICBP adalah sebesar 1,0000 pada Desember 2019, return tertinggi pada perusahaan INDF adalah sebesar 0,1981 pada Desember 2016 dan return terendah pada perusahaan INDF sebesar -1,0000 pada Desember 2019, return tertingggi pada perusahaan MLBI sebesar 0,3694 pada Maret 2017 dan return terendah sebesar -1,0000 pada Desember 2019, return terbesar pada perusahaan PSDN adalah sebesar 0,9928 pada Januari 2018 dan return terendah sebesar -1,0000 pada Desember 2019, return tertinggi pada perusahaan ROTI adalah sebesar 0,1328 dan return terendah sebesar -1,0000 pada Desember 2019 dan return tertinggi pada perushaan SKBM adalah sebesar 0,4533 pada November 2018 dan return terendah sebesar -1,0000 pada Desember 2019.

Salah satu faktor yang mempengaruhi naik turunya return sebuah saham adalah tingkat suku bunga. Kenaikan tingkat suku bunga akan berakibat terhadap menurunnya return saham begitu juga sebaliknya. Dalam menghadapi kenaikan suku bunga, para pemegang saham akan menahan sahamnya sampai tingkat suku bunga kembali kepada tingkat yang dianggap normal. Sebaliknya, jika suku bunga jangka panjang meningkat maka pemegang saham cenderung menjual sahamnya karena harga jual tinggi. Hal ini menujukkan bahwa PSDN memberikan return terbesar diantara saham lainnya yaitu sebesar 0,9928 pada Januari 2018 .

\section{Analisis Expected Return}

Expected return merupakan return yang diharapkan oleh investor. Expected return dihitung dengan cara membagi jumlah return aktual dengan periode penelitian. Berikut tabel 4 hasil analisis expected return:

\begin{tabular}{|c|c|}
\hline EMITEN & $\mathbf{E}(\mathbf{R i})$ \\
\hline CEKA & 0,0061 \\
\hline DLTA & $-0,0288$ \\
\hline ICBP & $-0,0219$ \\
\hline INDF & $-0,0133$ \\
\hline MLBI & $-0,0232$ \\
\hline PSDN & 0,0116 \\
\hline ROTI & $-0,0157$ \\
\hline SKBM & $-0,0202$ \\
\hline
\end{tabular}

Sumber : Hasil Olah Data, 2020 


\section{JURNAL AKUNTANSI, Vol. 10, No. 1, April (2021)}

Tabel 4 Expected Return E(Ri) menunjukkan saham-saham yang memberikan expected return yang terbesar adalah pada perusahaan Parasida Aneka Niaga Tbk, (PSDN) yaitu sebesar 0,0116. Hal menunjukkan bahwa kepercayaan investor kepada emiten semakin baik dan investor mempunyai harapan akan memperoleh keuntungan atau deviden yang besar, sedangkan saham yang memberi expected return (laba yang akan diperolah dari investasi yang dilakukan) yang paling kecil adalah perusahaan Delta Djakarta Tbk (DLTA) yaitu sebesar -0,0288 disebabkan melemahnya nilai tukar domestik terhadap mata uang asing (seperti rupiah terhadap US dolar) memberikan pengaruh negatif terhadap laba yang diharapkan investor dimasa yang akan datang.

\section{Analisis Return Market (Rm)}

Untuk menentukan return market $(\mathrm{Rm})$ maka digunakan data Indeks Harga Saham Gabungan (IHSG) sebagai indikator perhitungan. Hasil analisis data terhadap return market dapat dilihat pada grafik 1 berikut :

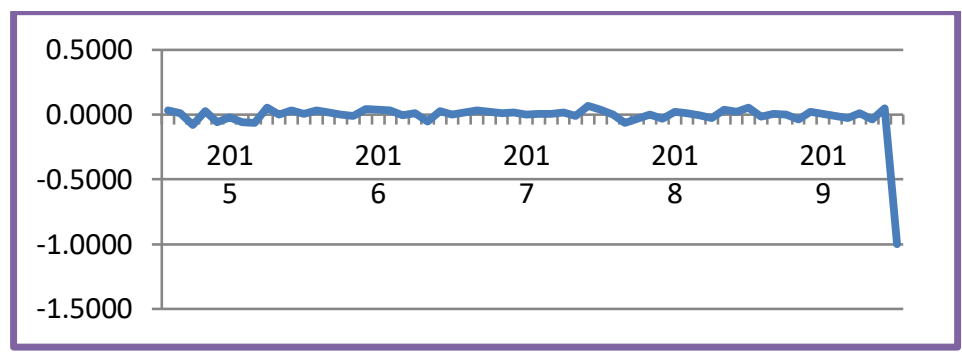

Sumber : Hasil Olah Data, 2020

Grafik 1. Nilai Return Market (Rm)

Grafik 1. menjelaskan bahwa tingkat pengembalian pasar (Rm) mengalami peningkatan pada bulan November 2017 sebesar 0,0678 (6,78\%) karena meningkatnya kepercayaan investor terhadap perekonomian dan tingkat pengembalian pasar mengalami penurunan pada bulan Desember 2019 sebesar -1,0000 disebabkan melemahnya mata uang rupiah terhadap mata uang asing sehingga mengakibatnya menurunya indeks harga saham gabungan, maka investor kembali mempertimbangkan untuk menginvestasikan sahamnya.

\section{Analisis Risk Free (Rf)}

Indikator yang digunakan untuk menghitung aset bebas risiko (risk free) dengan menggunakan BI 7-Day Repo Rate. Hasil analisis data terhadap risk free dapat dilihat pada grafik 2 berikut :

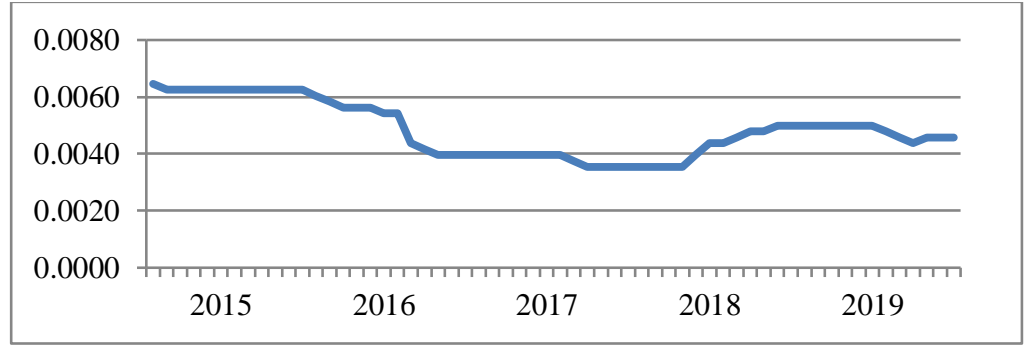

Sumber : Hasil Olah Data, 2020

Grafik 2. Nilai Risk Free (Rf)

Risk free merupakan aset pengembalian masa depan dapat diketahui dan diterima dengan pasti. Dari grafik 2 nilai risk free memperoleh nilai tertinggi sebesar 0,0065 $(0,65 \%)$ kenaikan ini akan menyebabkan biaya pinjaman semakin mahal, sehingga para investor cenderung menghindari tindakan meminjam dana dari bank, dengan hal tersebut dapat mengakibatkan berkurangnya investasi dan nilai terendah Risk free sebesar $0,0035(0,35 \%)$ menurunnya nilai risk free maka nilai pinjaman semakin murah, sehingga para investor terdorong untuk melakukan investasi. 


\section{Analisis Excess Return}

Excess Return merupakan kelebihan dari investasi di pasar modal dibandingkan investasi pada produk perbankan (tabungan atau deposito) yang menjadikan investasi tersebut dianggap menarik. Untuk menghitung excess return dapat dihitung dengan cara return individual dikurangi dengan risk free (Rf).

Nilai excess return yang pada perusahaan CEKA memperoleh nilai excess return tertinggi sebesar 0,5135 pada bulan Februari dan memperoleh nilai terendah sebesar -1,0046 pada bulan Desember 2019, excess return pada perusahaan DLTA memperoleh nilai tertinggi sebesar 0,1407 pada bulan Februari 2016 memperoleh nilai terendah sebesar -1,0046 pada bulan Desember 2019, nilai excess return pada perusahaan ICBP sebesar 0,1545 terjadi pada bulan Juli 2016 dan nilai terendah sebesar -1,0046 pada bulan Desember 2019, excess return pada perusahaan INDF sebesar 0,1918 terjadi pada bulan Desember 2015 dan nilai terendah sebesar -1,0046 pada bulan Desember 2019, excess return pada perusahaan MLBI sebesar 0,3638 pada bulan Maret 2016 dan nilai terendah sebesar -1,0046 pada bulan Desember 2019, nilai excess return pada perusahaan PSDN sebesar 0,9892 terjadi pada Januari 2018 dan nilai terendah sebesar -1,0046 pada bulan Desember 2019, excess return pada perusahaan ROTI sebesar 0,1329 pada Maret 2016 dan nilai terendah sebesar -1,0046 pada bulan Desember 2019 dan nilai excess return pada perusahaan SKBM sebesar 0,4997 pada November 2017 dan nilai terendah sebesar -1,0046 pada bulan Desember 2019.

Meningkatnya excess return dikarenakan laporan keuangan emiten bisa dilihat kinerja keuangan yang baik dari segi kemampuan menghasilkan keuntungan. Sedangkan akibat dari excess return menurun yaitu meningkatnya tingkat suku bunga jangka panjang sehingga investor cenderung menjual sahamnya karena harga jualnya tinggi. Hal ini menunjukkan bahwa PSDN memberikan nilai excess return tertinggi diantara saham lainnya yaitu sebesar 0,9892 pada Januari 2018 .

Analisis Varian, Standar Deviasi, Alpha, Beta, Varian Residual, dan Excess Return To Beta Tabel 5. Varian, Standar Deviasi, Alpha, Beta, Varian Residual dan Excess Return to Beta (ERB)

\begin{tabular}{cccrcrr} 
EMITEN & Varian & SD & $\boldsymbol{\alpha}$ & $\boldsymbol{\beta}$ & $\boldsymbol{\sigma}^{2} \boldsymbol{e i}$ & \multicolumn{1}{c}{ ERB } \\
\hline CEKA & 0,0374 & 0,1933 & 0,0193 & 0,9980 & 0,0548 & 0,0012 \\
DLTA & 0,0355 & 0,1884 & $-0,0166$ & 0,9200 & 0,0503 & $-0,0365$ \\
ICBP & 0,0327 & 0,1809 & $-0,0084$ & 1,0130 & 0,0507 & $-0,0263$ \\
INDF & 0,0216 & 0,1470 & $-0,0001$ & 1,0010 & 0,0391 & $-0,0181$ \\
MLBI & 0,0384 & 0,1959 & $-0,0114$ & 0,8860 & 0,0521 & $-0,0316$ \\
PSDN & 0,0768 & 0,2772 & 0,0247 & 0,9910 & 0,0940 & 0,0068 \\
ROTI & 0,0205 & 0,1433 & $-0,0029$ & 0,9660 & 0,0369 & $-0,0213$ \\
SKBM & 0,0391 & 0,1978 & $-0,0080$ & 0,9210 & 0,0540 & $-0,0275$ \\
\hline
\end{tabular}

Sumber : Hasil Olah Data, 2020

Hasil analisis yang terdapat pada tabel 5 menjelaskan nilai varian dari delapan (8) perusahaan tersebut. PSDN memiliki nilai varian tertinggi sebesar 0,0768 , hal ini mengindikasikan bahwa PSDN memperoleh tingkat return tertinggi. Dengan tingkat return yang tinggi maka tingkat risiko yang kemungkinan diperoleh juga tinggi. Selanjutnya tabel 4 menunjukkan bahwa alpha bervariatif, ada perusahaan yang mempunyai nilai alpha negatif dan positif. Nilai alpha negatif terjadi pada perusahaan DLTA sebesar -0,0166 sedangkan nilai alpha terbesar terdapat pada perusahaan PSDN sebesar 0,0247. 
Hasil lain menjelaskan nilai beta yang menunjukkan tingkat sensitifitas return saham terhadap return market. Hasil analisis diperoleh dua (2) saham yang memiliki nilai beta lebih besar dari 1 adalah perusahaan ICBP sebesar 1,0130 dan perusahaan INDF sebesar 1,0010, perusahaan yang nilai beta nya lebih besar dari satu artinya saham tersebut mempunyai kepekaan yang tinggi terhadap kondisi pasar sehingga tingkat keuntungan saham meningkat lebih besar dibandingkan denga tingkat keuntungan keseluruhan saham dipasar. Berdasarkan tabel 5 diatas dapat dilihat 6 saham yang nilai beta lebih kecil dari satu yaitu saham CEKA sebesar 0,9980, DLTA sebesar 0,9200, MLBI sebesar 0,8860, PSDN sebesar 0,9910, ROTI sebesar 0,9660, dan SKBM sebesar 0,9210, perusahaan yang memiliki nilai beta lebih kecil dari satu artinya saham tersebut kurang peka terhadap kondisi pasar sehingga tingkat keuntungan saham meningkat lebih kecil dibandingkan dengan tingkat keuntungan keseluruhan saham dipasar.

Berdasarkan perhitungan excess return to beta (ERB) yaitu kelebihan pengembalian atas return bebas risiko terhadap aset lain di peroleh dua (2) perusahaan yang memiliki nilai tertinggi yaitu Prasidha Aneka Niaga Tbk,(PSDN) sebesar 0,0068 dengan Wilmar Cahaya Indonesia Tbk (CEKA) sebesar 0,0012 karena saham tersebut memberi premi risiko lebih rendah bagi investor. Sementara terdapat 6 saham yang mempunyai nilai ERB yang terendah yaitu Multi Bintang Indonesia (MLBI) sebesar -0,0316, Delta Djakarta Tbk (DLTA) sebesar -0,0365, Indofood CBP Sukses Makmur (ICBP) sebesar -0,0263, Indofood Sukses Makmur (INDF) sebesar -0,0181, Nippon Indosari Corporindo Tbk (ROTI) sebesar -0,0213, Sekar Bumi Tbk (SKBM) sebesar 0,0275 , karena memberikan premi risiko yang tinggi bagi investor. Saham yang akan masuk kedalam portofolio optimal harus mempunyai nilai ERB yang tinggi.

\section{Analisis Cut-off Rate (Ci) dan Cut-off Point (C*)}

Nilai Ci merupakan hasil bagi variance market dan return premium terhadap variance error saham dengan variance market pada sensitivitas saham individual terhadap variance error residual saham. Cut-off Point $\left(\mathrm{C}^{*}\right)$ merupakan nilai $\mathrm{Ci}$ maksimum dari sederetan nilai $\mathrm{Ci}$ saham. Nilai $C^{*}$ digunakan untuk menentukan titik pembatas saham mana saja yang masuk sebagai kandidat portofolio optimal. Portofolio optimal dibentuk dari saham-saham yang mempunyai ERB lebih besar atau sama dengan cut-off rate.

\begin{tabular}{crr}
\multicolumn{3}{c}{ Tabel 6. Cut-off Rate (Ci) dan Cut-off Point $\left(\mathrm{C}^{*}\right)$} \\
\hline Emiten & Ci & \multicolumn{1}{c}{ C $^{*}$} \\
\hline CEKA & 0,0003 & 0,0011 \\
DLTA & $-0,0083$ & 0,0011 \\
INCB & $-0,0069$ & 0,0011 \\
INDF & $-0,0056$ & 0,0011 \\
MLBI & $-0,0066$ & 0,0011 \\
PSDN & $\mathbf{0 , 0 0 1 1}$ & 0,0011 \\
ROTI & $-0,0065$ & 0,0011 \\
SKBM & $-0,0059$ & 0,0011 \\
\hline
\end{tabular}

Sumber : Hasil Olah Data, 2020

Tabel 6. menjelaskan nilai Ci tertinggi terdapat pada perusahaan Prasidha Aneka Niaga (PSDN) sebesar 0,0011 dan perusahaan CEKA sebesar 0,0003. Hal ini menunjukkan batasan tertinggi dari deretan nilai $\mathrm{Ci}$ dari 8 saham perusahaan makanan dan minuman yang terdaftar di BEI. Nilai tertinggi dari $\mathrm{Ci}$ akan digunakan untuk menentukan $\mathrm{C}^{*}$. Ci terendah terdapat pada saham perusahaan Delta Djakarta (DLTA) sebesar -0,0083 hal menunjukkan bahwa DLTA merupakan batas terendah dari dari nilai Ci sehingga tidak digunakan untuk menentukan $\mathrm{C}^{*}$.

Nilai cut off point $\left(\mathrm{C}^{*}\right)$ adalah nilai tertinggi dari nilai cut off rate $(\mathrm{Ci})$ maksimum dari sederetan nilai cut off rate $(\mathrm{Ci})$ saham. Nilai cut off point digunakan sebagai titik pembatas untuk 
menentukan saham yang masuk kandidat portofolio optimal dengan saham yang tidak masuk dalam kandidat portofolio optimal.

\section{Analisis Portofolio Optimal}

Berikut ini perbandingan antara nilai ERB saham dengan nilai cut off rate-nya (Ci). Setelah dapat dihitung $\mathrm{Ci}$, maka nilai ERB yang disusun dari yang terbesar hingga terkecil dibandingkan dengan nilai cut off rate-nya. Jika ERB lebih besar dari cut off rate nya maka saham tersebut memenuhi kriteria untuk masuk kedalam portofolio optimal dan jika ERB saham lebih kecil dari nilai cut off point $(\mathrm{Ci})$ maka saham tersebut tidak memenuhi kriteria untuk masuk kedalam portofolio optimal.

Tabel 7. Kandidat Saham Makanan dan Minuman dalam Portofolio Optimal

\begin{tabular}{ccrc}
\hline Emiten & ERB & Ci & Keterangan \\
\hline PSDN & 0,0068 & 0,0011 & Kandidat \\
CEKA & 0,0012 & 0,0003 & Kandidat \\
DLTA & $-0,0365$ & $-0,0083$ & - \\
INDF & $-0,0181$ & $-0,0056$ & - \\
ROTI & $-0,0213$ & $-0,0065$ & - \\
ICBP & $-0,0263$ & $-0,0069$ & - \\
SKBM & $-0,0272$ & $-0,0059$ & - \\
MLBI & $-0,0316$ & $-0,0066$ & - \\
\hline
\end{tabular}

Sumber: Hasil Olah Data, 2020

Berdasarkan tabel 7 diatas maka dapat jelaskan bahwa perusahaan yang masuk dalam kandidat portofolio optimal adalah perusahaan adalah Prasidha Aneka Niaga (PSDN) dengan nilai ERB sebesar 0.0068 dan nilai $\mathrm{Ci}$ sebesar 0,0011 dan perusahaan Wilmar Cahaya Indonesia (CEKA) dengan nilai ERB sebesar 0,0012 dan nilai Ci sebesar 0,0003, karena nilai ERB lebih besar dari pada nilai Ci. Sedangkan ada 6 perusahaan yang tidak masuk kedalam portofolio optimal yaitu DLTA, INDF, ROTI, ICBP, MLBI, dan SKBM karena nilai ERB nya lebih kecil dari nilai $\mathrm{Ci}$. Hal ini mengindikasikan bahwa PSDN dan CEKA dapat membentuk portofolio optimal melalui diversifikasi dengan tujuan mengurangi risiko investasi.

\section{PEMBAHASAN}

Investasi merupakan dana yang tidak digunakan untuk kegiatan konsumsi dengan tujuan untuk mendapatkan keuntungan di masa. Dalam melakukan investasi, investor dihadapkan pada kondisi ketidakpastian (risiko), oleh karena investor harus memiliki kemampuan untuk menganalisis berbagai ketidakpastian yang mungkin terjadi di masa depan. Untuk menghindari ketidakpastian (risiko), maka investor dapat melakukan diversifikasi saham yaitu mengalokasikan dana pada berbagai jenis investasi untuk mengurangi risiko. Salah satu cara diversifikasi yaitu dengan pembentukan portofolio optimal saham.

Metode yang digunakan dalam pembentukan portofolio optimal ini adalah dengan menggunakan model indeks tunggal. Penggunaan model indeks tunggal ini dilakukan untuk menentukan portofolio optimal yaitu berdasarkan nilai cut-off rate dan excess return to beta (ERB). Apabila nilai ERB lebih besar atau sama dengan cut-off rate maka saham-saham tersebut masuk sebagai kandidat portofolio optimal. Kelebihan menggunakan cut-off rate dan ERB dalam penentuan portofolio optimal karena mempertimbangkan risiko sistematis yang diukur dengan beta.

Hasil penelitian mengungkapkan bahwa dari delapan (8) perusahaan makanan dan minuman ternyata hanya dua (2) perusahaan yang dapat membentuk portofolio optimal, yaitu PSDN dan CEKA. Hal ini dikarenakan kedua saham perusahaan tersebut memiliki expected return yang besar dengan 
premi risiko yang rendah bagi investor diantara saham makanan dan minuman lainnya, dengan kata lain tingkat pengembalian yang diperoleh sesuai dengan risiko yang dapat ditanggung oleh investor.

Faktor lainnya adalah saham PSDN dan CEKA memiliki proporsi dana tertinggi dibandingkan saham lainnya, hal ini mengindikasikan bahwa kedua saham tersebut dapat dijadikan alternatif investasi bagi investor. Kelebihan investasi dalam bentuk portofolio dibanding aset tunggal mengindikasikan bahwa tingkat risiko dapat dikurangi tanpa harus mengurangi tingkat keuntungan yang diharapkan.

Hasil penelitian ini sejalan dengan penelitian sebelumnya yang dilakukan oleh Rarastiti, Handayani dan Sudjana (2014) dan Oktaviani dan Wijayanto (2016) yang menunjukkan bahwa dengan melakukan diversifikasi dapat menurunkan risiko dilihat dari risiko portofolio yang lebih kecil dibandingkan dengan risiko individual saham. Hal ini memberikan investor lebih banyak pilihan dalam memilih saham-saham yang akan dijadikan alternatif dalam berinvestasi. Selain itu besarnya proporsi masing-masing saham berbeda satu dengan yang lain karena adanya perbedaan harga saham, tingkat keuntungan dan risiko individu yang menyertai saham-saham tersebut.

\section{PENUTUP}

\section{Simpulan}

Berdasarkan hasil penelitian yang telah dilakukan, maka dapat ditarik kesimpulan sebagai berikut:

Hakekat pembentukan portofolio adalah untuk mengurangi risiko dengan melakukan diversifikasi. Analisis pembentukan portofolio optimal dengan indeks tunggal menghasilkan dua saham yang menjadi kandidat portofolio yaitu PSDN dan CEKA. Dari dua saham ini diperlukan pembagian proporsi masing-masing saham untuk mendapatkan return terbaik dan juga risiko terbaik sesuai dengan besarnya proporsi masing-masing saham. Hal ini dilakukan karena adanya perbedaan harga saham, tingkat keuntungan dan risiko individu yang menyertai saham-saham tersebut. keterbatasan dalam penelitian ini adalah tidak semua perusahaan makanan dan minuman dijadikan sampel dalam penelitian sehingga dalam melakukan analisis terhadap pembentukan portofolio optimal hanya diperoleh dua perusahaan saja.

\section{Saran}

Dari hasil kesimpulan diatas dapat disarankan sebagai berikut:

Bagi investor dan calon investor, sebaiknya investor dan calon investor juga melakukan penilaian terhadap masing-masing saham dengan melihat kecenderungan pergerakan harga saham setiap bulannya. Bagi perusahaan yang sahamnya belum memenuhi syarat untuk masuk dalam portofolio optimal, dapat melakukan perbaikan kinerja perusahaannya agar sahamnya meningkat. Peneliti selanjutnya sebaiknya menambah jumlah sampel perusahaan berdasarkan pada industri yang berbeda sehingga perhitungan kombinasi portofolionya diharapkan lebih akurat.

\section{REFERENSI}

Astawinetu, Erwin Dyah \& Ni Wayan Soebrati. 2017. Analisis Perbandingan Risk \& Return Portofolio Saham First Liner \& Second Liner Dengan Metode Indeks Tunggal (Studi Kasus Pada SahamSaham Perusahaan Makanan dan Minuman yang Terdaftar di BEI Periode 2012-2014). Jurnal Ekonomi Manajemen, Vol. 2, No. 1.

Elton, Edwin J. and Martin J. Gruber. 1995. Modern Portfolio Theory and Investment Analysis. Toronto: John Wiley \& Sons.

Firdaus,Y.2015. Konsep Pemilihan Lokasi dan Efektivitas Pasar. http://eprints.uns.ac.id /22622/3/I0611026_bab2.pdf. Diakses pada 25 Januari 2020.

Jogiyanto, H. 2014. Teori Portofolio dan Analisis Investasi. Jakarta : Salemba empat. 
Mulyati, Murni. 2018. Analisis Investasi Dan Penentuan Portofolio Saham Optimal Dengan Metode Indeks Tunggal (Studi Empiris Pada IDX 30 Yang Terdaftar Di Di Bursa Efek Indonesia Periode Agustus 2017-Januari 2018). Jurnal Akuntansi dan Keuangan, Volume 6 nomor 2. Diunduh Agustus 2018.

Oktaviani, Berlian Nanda, \& Andhi Wijayanto, 2016. Aplikasi Single Index Model dalam Pembentukan Portofolio Optimal Saham LQ45 dan Jakarta Islamic Index. Vol. 5 No. 3 (2016): Management Analysis Journal.

Qudis, Suhartono. 2009.Portofolio Dan Bursa Efek.Yogyakarta: YKPN.

Rarastiti, Hanggi., Siti Ragil Handayani \& Nengah Sudjana. 2014. Pembentukan Portofolio Optimal dengan Menggunakan Single Index Model (Studi Pada Perusahaan Food and Beverages yang Terdaftar di BEI periode 2008-2011). Jurnal Administrasi Bisnis.6 (1), pp:1-10.

Sulistiyowati,Endang. 2017. Analisis Portofolio Optimal Model Indeks Tunggal pada Perusahaan Properti and Real Estate. Jurnal Ilmu dan Riset Manajemen, Volume,6 nomor 5. Diunduh 2017.

Syahyunan. 2015. Manajemen Keuangan. Medan: USA Press.

Tandelilin, Eduardus. 2017. Portofolio dan Investasi Teori dan Aplikasi, Edisi Pertama. Yogyakarta. Yuniarti.2010. Pembentukan Portofolio Optimal Saham - Saham Perbankan Dengan Menggunakan Model Indeks Tunggal. Jurnal keuangan dan perbankan Vol. 14, No. 3 September 2010.

Zubir, Z.2011. Manajemen Portofolio : Penerapanya dalam Investasi Saham,Edisi Pertama. Jakarta: Salemba Empat.

http://finance.yahoo.com , Harga saham, (29 Januari 2020)

http://www.bi.go.id, BI 7 day repo rate, (29 Januari 2020) 